\title{
REP-PCR Analysis to Study Prokaryotic Biodiversity from Lake Meyghan
}

\author{
Ali Naghoni ${ }^{1, a}$, Giti Emtiazi ${ }^{1, * b}$, Mohammad Ali Amoozegar ${ }^{2,3, c}$, \\ Zahra Etemadifar ${ }^{1, \mathrm{~d}}$, Seyed Abolhassan Shahzadeh Fazeli ${ }^{2,4, e}$ \\ ${ }^{1}$ Department of Biology, Faculty of Science, University of Isfahan, Isfahan, Iran \\ ${ }^{2}$ Microorganisms Bank, Iranian Biological Resource Centre (IBRC), ACECR Tehran-Iran \\ ${ }^{3}$ Extremophiles Laboratory, Department of Microbiology, Faculty of Biology and Center of \\ Excellence in Phylogeny of Living Organisms, College of Science, University of Tehran, \\ Tehran, Iran \\ ${ }^{4}$ Department of Molecular and Cellular Biology, Faculty of Basic Sciences and Advanced \\ Technologies in biology, University of Science and Culture, Tehran, Iran \\ aalinaghoni@gmail.com, bemtiazi@yahoo.com, alamoze@yahoo.com, \\ dz.etemadifar@sci.ui.ac.ir, ${ }^{\mathrm{e}}$ fazeli@ibrc.ir
}

Keywords: rep-PCR, 16S rRNA, microbial community, qPCR, prokaryotes

\begin{abstract}
Repetitive extragenic palindromic elements-polymerase chain reaction (rep-PCR) with $16 \mathrm{~S}$ ribosomal ribonucleic acid (16S rRNA) genes sequences successfully used for the analysis of microbial community. In this study, the prokaryotic community in Lake Meyghan described by using rep-PCR analysis along with 16S rRNA gene sequencing. The water samples were collected from Lake Meyghan in November 2013. All samples were diluted and cultured on three different media. To estimate the number of prokaryotes per milliliter of the lake we used quantitative real-time PCR (qPCR). Rep-PCR combination with 16S rRNA gene sequencing was performed to investigate prokaryotes biodiversity in the lake. 305 strains were isolated in this work; 113 isolates for green region, 102 isolates for red region, and 90 isolates for white region. The dendrograms generated 10, 7, and 9 clusters for a $70 \%$ similarity cut-off for green, red, and white regions, respectively. Based on rep-PCR and 16S rRNA gene sequencing, the recovered isolates were dominated by $(77.5 \%)$ Halobacteriacae and many isolates were related to the genera Halorubrum, Haloarcula, Haloterrigena, Natrinema, and Halovivax in the white region. In the red region more isolated strains $(57.5 \%$ ) belonged to Bacillaceae and the remaining $42.5 \%$ of isolates belonged to archaea domain, Halorubrum, and Haloarcula. In the green region members of Gammaproteobacteria were recovered, this region was dominant with Pseudoalteromonas, Salinivibrio, and Aliidiomarina.
\end{abstract}

\section{Introduction}

Microorganisms despite their small size have a vast impact on our lives. In the 1960s, microbiologists began exploring the impact of biodiversity on the structure and function of microbial communities [1,2]. Understanding patterns of prokaryotes (bacteria and archaea) biodiversity is of particular importance for the reason that prokaryotes may well comprise the majority of the earth's species diversity, many processes responsible for sustaining life on earth are mediated by them therefore their diversity is practically very important in bioprospecting (the search for novel biochemicals for use in medicine, agriculture, and industry) and bioremediation (the biological degradation of pollutants) [3-5].

Saline and hypersaline environments are very useful in studies on prokaryotes diversity. On the one hand, prokaryotes diversity decreases with increasing salinity [5-8]. On the other hand, aquatic hypersaline systems have proved to be an excellent source of new culturable microorganisms [9-12]. Hypersaline environments can be separated into two types, thalassohaline and athalassohaline [13]. Thalassohaline aquatic environments have an ionic compositions similar 
to seawater with $\mathrm{NaCl}$ as dominant salt $[14,15]$. A Thalassohaline aquatic environments are formed by dissolution of mineral salt deposits of continental origin that are dominated by $\mathrm{K}^{+}, \mathrm{Mg}^{2+}, \mathrm{Na}^{+}$, and $\mathrm{CO}_{3}{ }^{2-}$ ions such as can be found in the soda lakes $[15,16]$. Many ecological studies were performed with useful molecular techniques in both athalassohaline and thalassohaline hypersaline habitats [17-21].

To date, repetitive extragenic palindromic elements-polymerase chain reaction (rep-PCR) has become one of the highly reliable and widely used techniques for studies of molecular diagnostics, microbial ecology, environmental, and medical microbiology. This unique technique provides a very easy, quick, and inexpensive way to detect diversity of the microbial genomes being studied $[22,23]$. Albeit, other genomic DNA methods are also useful to group and identify microbes, the rep-PCR is a method known for its simplicity, rapidity, and cost effectiveness which enjoys the essential resolving power need for microbial identification [24]. This technique is often used for epidemiological analyses, genotyping, and strain tracking purposes but some researchers recently used this technique with/without $16 \mathrm{~S}$ ribosomal ribonucleic acid (16S rRNA) genes sequences successfully for analyzing microbial community [25-27].

Microbial genomes include many different types of repetitive DNA elements, make up $5 \%$ of the whole genome [28-30]. Albeit, some repetitive elements (e.g. Mycobacterium leprae-specific repetitive element) are particularly existent in a limited group of bacteria, others, such as the rep DNA sequences, have been seen among many groups of phylogenetically diverse archaea and bacteria [30-32]. Since each microbial strain has repetitive elements located in distinct positions around their genome, the PCR method, performed using these repetitive sequences as primers and genomic DNA as template, generates banding patterns and can act as a barcode for a specific strain of microorganisms [33]. Rep-PCR is a method known for its simplicity, rapidity, and cost effectiveness and when this technique is coupled with 16S rRNA gene sequencing technique could have reliable results and give us excellent idea about the diversity of the regions being studied. [2527, 32].

Iran has a great diversity of hypersaline habitats such as Lake Urmia, Lake Meyghan, AranBidgol salt lake, and Howz-e Soltan salt lake. Lake Meyghan is one of the most important hypersaline lakes in Iran, because of its large mineable sodium sulfate deposits, the largest in the Middle East [34]. Lake Meyghan covers an area of $110 \mathrm{~km}^{2}$ in the central part of Iran (Markazi province, north of Arak city). The lake itself is located in an area with an arid to semi-arid continental climate and temperature ranges from $+40{ }^{\circ} \mathrm{C}$ in summer to $-30{ }^{\circ} \mathrm{C}$ in winter [34].

Since rep-PCR is a simple, rapid and cost effective and inexpensive technique to investigate and obtain quick and basic information about microbial communities, we decided to describe the prokaryotic community in Lake Meyghan by using rep-PCR analysis along with 16S rRNA gene sequencing.

\section{Materials and Methods}

\section{Sample sites, samples collection and growth conditions}

The Lake Meyghan (34¹1'-27.91"N, 4950'-26.70"E) was sampled in November 2013. We sampled the lake at three different sites named according to brine color. These were $\mathrm{G}$ (green, $34^{\circ} 11^{\prime}-21.59^{\prime \prime} \mathrm{N}, 49^{\circ} 50^{\prime}-45.73 " \mathrm{E}$ ), R (red, 34 $11^{\circ}-20.78^{\prime \prime} \mathrm{N}, 49^{\circ} 50^{\prime}-21.87^{\prime \prime} \mathrm{E}$ ), and $\mathrm{W}$ (white, $34^{\circ} 11^{\prime}-$ $\left.35.31 " \mathrm{~N}, 49^{\circ} 50^{\prime}-18.25^{\prime \prime} \mathrm{E}\right)$. The samples were collected aseptically and transferred to the lab within four hours. The $\mathrm{pH}$ and salinity of the samples were measured in situ with portable meter PT-10P (Sartorius, Germany). Prokaryotes isolated under aerobic conditions on three growth media. The Modified Growth Medium (MGM) medium contained $\left(\mathrm{g} \mathrm{L}^{-1}\right)$ : $\mathrm{NaCl} 184.8, \mathrm{MgSO}_{4} .7 \mathrm{H}_{2} \mathrm{O} 26.9$, $\mathrm{MgCl}_{2} \cdot 6 \mathrm{H}_{2} \mathrm{O} 23.1$, peptone $10.0, \mathrm{KCl} 5.4$, yeast extract $2.0, \mathrm{CaCl}_{2} .2 \mathrm{H}_{2} \mathrm{O} 0.8$, and agar $15.0 ; \mathrm{pH} 7.2$ at $25{ }^{\circ} \mathrm{C}$. Moderately Halophilic medium $(\mathrm{MH})$ contained of $\left(\mathrm{g} \mathrm{L}^{-1}\right): \mathrm{NaCl} 81.0, \mathrm{MgSO}_{4} .7 \mathrm{H}_{2} \mathrm{O} 9.6$, $\mathrm{MgCl}_{2} .6 \mathrm{H}_{2} \mathrm{O} 7.0, \mathrm{KCl} 2.0, \mathrm{CaCl}_{2} 0.54$, glucose 1.0, proteose peptone 5.0, yeast extract 10.0, agar 15.0, $\mathrm{NaBr} 0.026$, and $\mathrm{NaHCO}_{3}$ solution $10.0 \mathrm{~mL}$ (Add $0.06 \mathrm{~g} \mathrm{NaHCO}_{3}$ to $10.0 \mathrm{~mL}$ of deionized water ); $\mathrm{pH} 7.5$ at $25{ }^{\circ} \mathrm{C}$. Marine medium contained of $\left(\mathrm{g} \mathrm{L}^{-1}\right)$ : $\mathrm{NaCl} 19.45, \mathrm{MgCl}_{2}$ (anhydrous) 
5.90, peptone 5.0, $\mathrm{Na}_{2} \mathrm{SO}_{4} 3.24, \mathrm{CaCl}_{2}$ 1.80, yeast extract $1.0, \mathrm{KCl} 0.55, \mathrm{NaHCO}_{3} 0.16, \mathrm{Fe}$ (III) citrate $0.10, \mathrm{KBr} 0.08, \mathrm{SrCl}_{2}$ 0.034, $\mathrm{H}_{3} \mathrm{BO}_{3}$ 0.022, $\mathrm{Na}_{2} \mathrm{HPO}_{4}$ 0.008, Na-silicate 0.004, NaF 0.0024, $\left(\mathrm{NH}_{4}\right) \mathrm{NO} 30.0016$, and agar $15.0 ; \mathrm{pH} 7.6$ at $25^{\circ} \mathrm{C}$. All samples were serially diluted up to $10^{-6}$ and plated according to Burns et al. [35]. The plates were incubated aerobically at two different temperatures 30 and $40{ }^{\circ} \mathrm{C}$ for 8 weeks.

\section{DNA extraction and Quantitative real-time PCR (qPCR)}

Environmental DNA was extracted as described previously $[35,36]$. Bacterial and archaeal genomic DNA was extracted by the DNP ${ }^{\mathrm{TM}}$ kit (Cinnagen, Iran), according to the manufacturer's recommendations. DNA concentration and purity were spectrophotometrically assessed by reading $\mathrm{A}_{260}$ and $\mathrm{A}_{280}$ and confirmed by visualization on $1 \%$ agarose gel.

The standard curves and qPCR were performed as described previously [37]. Plasmid DNA possessing a full-length copy of 16S rRNA gene belonging either to the Halorubrum chaoviator (DSM 19316) and Escherichia coli (ATCC 25922) were used as DNA standards in qPCR. The target DNA for standard curves were amplified using the species-specific primer sets $27 \mathrm{~F}$ and $1492 \mathrm{R}$ for bacteria and $20 \mathrm{~F}$ and $1530 \mathrm{R}$ for archaea (Table 1) [38, 39]. Copy number per $\mu \mathrm{L}$ of extracted DNAs were calculated using formula

$$
\text { Copy number per } \mu \mathrm{L}=\frac{\text { concentration of plasmids }(\mathrm{gm} / \mu \mathrm{L}) \times 6.023 \times 10^{23}}{\text { length of recombinant plasmid }(\mathrm{bp}) \times 660}
$$

$\left(660=\right.$ Molecular weight of one basepair in double-stranded DNA, $6.023 \times 10^{23}=$ Avogadro's number) [40]. qPCR was performed with Rotor-Gene ${ }^{\mathrm{TM}} 6000$ (Corbett Research Biosciences, Sydney, Australia) using the species-specific primer sets Eub338 and Eub518 for bacteria samples and Parch519F and ARC915R for archaea samples (Table 1) [38, 41-43]. Amplification were performed in a total volume of $15 \mu \mathrm{L}$, containing $30 \mathrm{ng}$ of template DNA, $7.5 \mu \mathrm{L}$ of $2 \mathrm{X}$ Maxima SYBR Green qPCR Master Mix (Fermentas, France), $1.5 \mu \mathrm{L}$ of each primer $(10 \mathrm{pmol} / \mu \mathrm{L})$ and sterile $\mathrm{H}_{2} \mathrm{O}$. The amplification program involved an initial denaturation step at $95{ }^{\circ} \mathrm{C}$ for $15 \mathrm{~min}$, followed by 40 cycles of $94{ }^{\circ} \mathrm{C} 30 \mathrm{~s}, 60{ }^{\circ} \mathrm{C}$ for $30 \mathrm{~s}$ and $72{ }^{\circ} \mathrm{C} 20 \mathrm{~s}$ for both bacteria and archaea. For all standard curves, the coefficients of determination $\left(\mathrm{R}^{2}\right.$ value $)$ were higher than $99.0 \%$. The number of target genes per $\mathrm{mL}$ of sample was calculated using formula [40]

Number of gene copies per mL samples $=\frac{(\text { gene copies per reaction mix }) \times(\text { volume of DNA }[\mu \mathrm{L}])}{(3 \mu \mathrm{L} \text { DNA per reaction mix }) \times(\text { mL sample used })}$.

Table 1. List of oligonucleotides used in this study.

\begin{tabular}{|c|c|c|}
\hline Primer Name & Primer Sequence (5' to 3') & Reference \\
\hline $27 \mathrm{~F}$ & AGAGTTTGATCMTGGCTCAG & 38 \\
\hline $1492 \mathrm{R}$ & GGTTACCTTGTTACGACTT & 38 \\
\hline $20 \mathrm{~F}$ & TCCGGTTGATCCTGCCG & 39 \\
\hline $1530 \mathrm{R}$ & AAGGAGGTGATCCAGCC & 39 \\
\hline Eub338 & ACTCCTACGGGAGGCAGCAG & 38 \\
\hline Eub518 & ATTACCGCGGCTGCTGG & 41 \\
\hline Parch519F & CAGCCGCCGCGGTAA & 42 \\
\hline ARC915R & GTGCTCCCCCGCCAATTCCT & 43 \\
\hline REP1R & IIIICGICGICATCIGGC & 44 \\
\hline REP2I & ICGICTTATCIGGCCTAC & 44 \\
\hline
\end{tabular}




\section{Rep-PCR analysis}

The primers used for the rep-PCR reaction were REP1R and REP2I (Table1) [44]. DNA amplification was carried out using approximately $100 \mathrm{ng}$ genomic DNA. The amplification program involved an initial denaturation cycle for $7 \mathrm{~min}$ at $95^{\circ} \mathrm{C}$, followed by 35 cycles of $30 \mathrm{~s}$ at $90{ }^{\circ} \mathrm{C}, 1 \mathrm{~min}$ annealing at $40^{\circ} \mathrm{C}, 8 \mathrm{~min}$ extension at $72{ }^{\circ} \mathrm{C}$ and $16 \mathrm{~min}$ final extension at $72{ }^{\circ} \mathrm{C}$. The reaction mixture contained $12.5 \mu \mathrm{L} \mathrm{GoTaq}^{\circledR} \mathrm{G} 2$ Master Mix (Promega, Madison, USA), $1 \mu \mathrm{L}$ of each primer $(10 \mathrm{pmol} / \mu \mathrm{L})$. The PCR product underwent $1 \%$ agarose gel electrophoresis for $3 \mathrm{~h}$ under constant $80 \mathrm{~V}$ in $0.5 \mathrm{X}$ TBE, gels were stained with ethidium bromide, visualized under ultraviolet (UV) radiation and photographed.

The rep-PCR were analyzed using the BioNumerics software package version 6.6.11 (Applied Maths NV, Sint-Martens-Latem, Belgium). Using the Jaccard algorithm [23]. Clusters were considered at a $70 \%$ similarity cut-off [24].

\section{PCR amplification of 16S rRNA genes and sequence analysis}

After generating the dendrograms based on the rep-PCR analysis, the 34 representative isolates for all regions and each cluster were subjected to 16S rRNA genes sequencing analysis. These isolates were amplified using either bacteria domain-specific primer 27F and 1492R or archaea-specific primer 20F and 1530R (Table 1) [38, 39]. The PCR conditions were as follows for bacteria: $94^{\circ} \mathrm{C}$ for $3 \mathrm{~min}$, followed by 25 cycles of $95{ }^{\circ} \mathrm{C}$ for $45 \mathrm{~s}, 55^{\circ} \mathrm{C}$ for $45 \mathrm{~s}$ and $72{ }^{\circ} \mathrm{C}$ for $90 \mathrm{~s}$, with final $10 \mathrm{~min}$ extension at $72{ }^{\circ} \mathrm{C}$ and for archaea: $94{ }^{\circ} \mathrm{C}$ for $3 \mathrm{~min}$, followed by 30 cycles of $94{ }^{\circ} \mathrm{C}$ for $15 \mathrm{~s}, 52{ }^{\circ} \mathrm{C}$ for $30 \mathrm{~s}$ and $72{ }^{\circ} \mathrm{C}$ for $50 \mathrm{~s}$, with final 7 min extension at $72{ }^{\circ} \mathrm{C}$.

Relevant sequences were extracted from GenBank (www.ncbi.nlm.nih.org) using BLASTN and through the EzBioCloud server (www.ezbiocloud.net/eztaxon) [8]. The sequences were considered to belong to an operational taxonomic unit (OTU) if they shared $\geq 97 \%$ sequence identity.

Maximum likelihood searches under a General-Time-Reversible (GTR) substitution model with gamma distributed rate heterogeneity and a proportion of invariable sites $(\mathrm{GTR}+\Gamma+\mathrm{I})$ were calculated using MEGA version $5[45,46]$.

\section{Nucleotide sequence accession numbers}

The 16S rRNA gene sequences determined in this study have been deposited in the GenBank sequence database under accession numbers KX351831-KX351864.

\section{Results}

The physicochemical properties of water samples collected are presented in Table 2. The temperature of all sites were the same. The salinity of green, red, and white sites were $5 \%, 18 \%$, and $30 \%$, respectively. With a $\mathrm{pH}$ of $8.8,7.9$, and 7.7 in green, red, and white sites, respectively. We identified $\mathrm{Na}^{+}$and $\mathrm{Cl}^{-}$major ions in the all samples. Total prokaryote cells per $\mathrm{mL}$ of samples determined by qPCR were ranged 3.6-8.1 $\times 10^{6}$. The abundance of bacterial and archaeal cells determined with bacteria-specific primers and archaea-specific primers represent $15.7 \%-79 \%$ and $21 \%-84.3 \%$ of target genes per $\mathrm{mL}$ of samples, respectively. The abundance of bacterial cell was more significant in green site $(79 \%)$, while the abundance of archaeal cell was more dominant in white and red sites $(84.3 \%$ and $78.1 \%)$.

In total, 305 strains were isolated; 113 isolates for the green region, 102 isolates for the red region, and 90 isolates for the white region. Out of these isolates, 120 isolated strains (40 isolates for each region) were randomly selected to generate dendrogram based on rep-PCR analysis. The abundance of bacterial and archaeal in all samples, determined by qPCR, was reported as the number of target genes per $\mathrm{mL}$ of samples (Table 2). For all standard curves, the coefficients of determination $\left(\mathrm{R}^{2}\right.$ value) were higher than $99.0 \%$ (Fig. 1). 
Table 2. Physico-chemical properties of water samples, total cell count and relative percentages of bacterial and archaeal cells in each sample with species-specific primers by using qPCR.

\begin{tabular}{|c|c|c|c|}
\hline & Green & Red & White \\
\hline Parameter: & & & 30 \\
\hline Salinity $(\%)$ & 5 & 7.9 & 7.7 \\
\hline $\mathrm{pH}$ & 8.8 & 15 & 15 \\
\hline Temperature $\left({ }^{\circ} \mathrm{C}\right)$ & 15 & & \\
\hline Ion concentration $\left(\mathrm{g} \mathrm{L}^{-1}\right)$ : & & 64.7 & 111.5 \\
\hline $\mathrm{Na}^{+}$ & 8.6 & 0.56 & 0.55 \\
\hline $\mathrm{Ca}^{2+}$ & 0.38 & 0.19 & 0.20 \\
\hline $\mathrm{K}^{+}$ & 0.06 & 92.6 & 164.1 \\
\hline $\mathrm{Cl}^{-}$ & 11.6 & 0.76 & 0.22 \\
\hline $\mathrm{HCO}_{3}^{-}$ & 0.16 & $\begin{array}{c}1.2 \times 10^{6} \\
(21.9 \%)\end{array}$ & $\begin{array}{c}5.6 \times 10^{5} \\
(15.7 \%)\end{array}$ \\
\hline $\begin{array}{l}\text { Number of bacteria per mL of samples }(\%) \\
(79 \%)\end{array}$ & $\begin{array}{c}1.7 \times 10^{6} \\
(21 \%)\end{array}$ & $\begin{array}{c}4.3 \times 10^{6} \\
(78.1 \%)\end{array}$ & $\begin{array}{c}3.0 \times 10^{6} \\
(84.3 \%)\end{array}$ \\
\hline $\begin{array}{l}\text { Number of archaea per mL of samples }(\%) \\
\text { Total (number of prokaryote cells per } \mathrm{mL}\end{array}$ & $\begin{array}{c}8.1 \times 10^{6} \\
\text { of samples }\end{array}$ & $\begin{array}{c}5.5 \times 10^{6} \\
3.6 \times 10^{6}\end{array}$ \\
\hline
\end{tabular}

A)

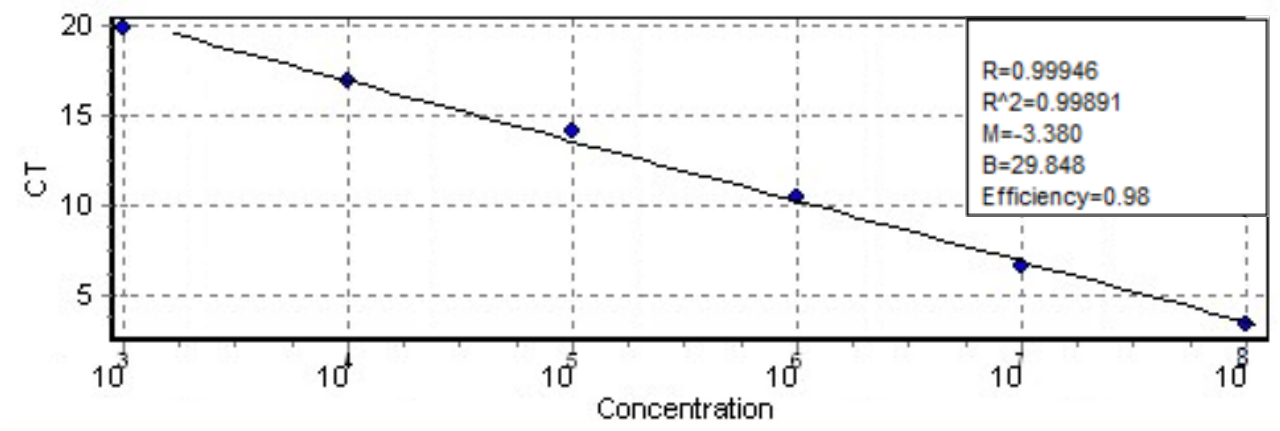

B)

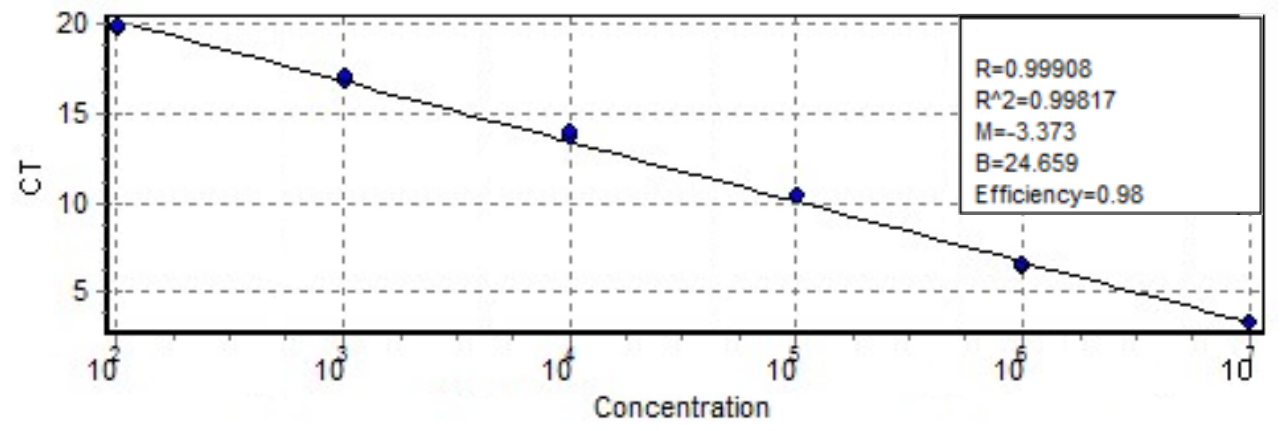

Figure 1. Standard curves with the CT plotted against the concentrations of the target DNAs

(Halorubrum chaoviator (DSM 19316) for archaea and Escherichia coli (ATCC 25922) for bacteria). A standard curve was generated using a 10-fold serial dilution of target DNAs amplified on the Rotor-Gene ${ }^{\mathrm{TM}}$ 6000. A) for bacteria B) for archaea. CT: cycle threshold; R: square root of correlation coefficient; $\mathrm{R}^{\wedge} 2$ : R2: correlation coefficient; $\mathrm{M}$ : slope; B: intercept. 
The dendrograms generated 10,7, and 9 clusters for a $70 \%$ similarity cut-off for the green, red, and white regions, respectively (Fig. 2-4). This same cut-off enabled the observation of a large clusters in different regions; cluster $\mathrm{H}$ in the green region with 13 isolates, clusters $\mathrm{K}, \mathrm{M}, \mathrm{O}$ in the red region with 10, 8 , and 11 isolates, respectively, and clusters $\mathrm{R}, \mathrm{T}$, and $\mathrm{U}$ in the white region with 9, 7, and 9 isolates, respectively. The similarity between the most distant isolates for the green, red, and white regions were $44 \%, 32 \%$, and $46 \%$, respectively (Fig. 2-4). Site green presented the highest diversity with 10 clusters (between $100 \%$ and $44 \%$ ), designated A, B, C, D, E, F, G, H, I, and $\mathrm{J}$ (Fig. 2). Site red had lower diversity, with 7 clusters (between $100 \%$ and 32\%), designated K, L, M, N, O, P, and Q (Fig. 3). Site white had 9 clusters (between 100\% and 46\%), designated R, S, T, U, V, W, Y, Z, and \& (Fig. 4).

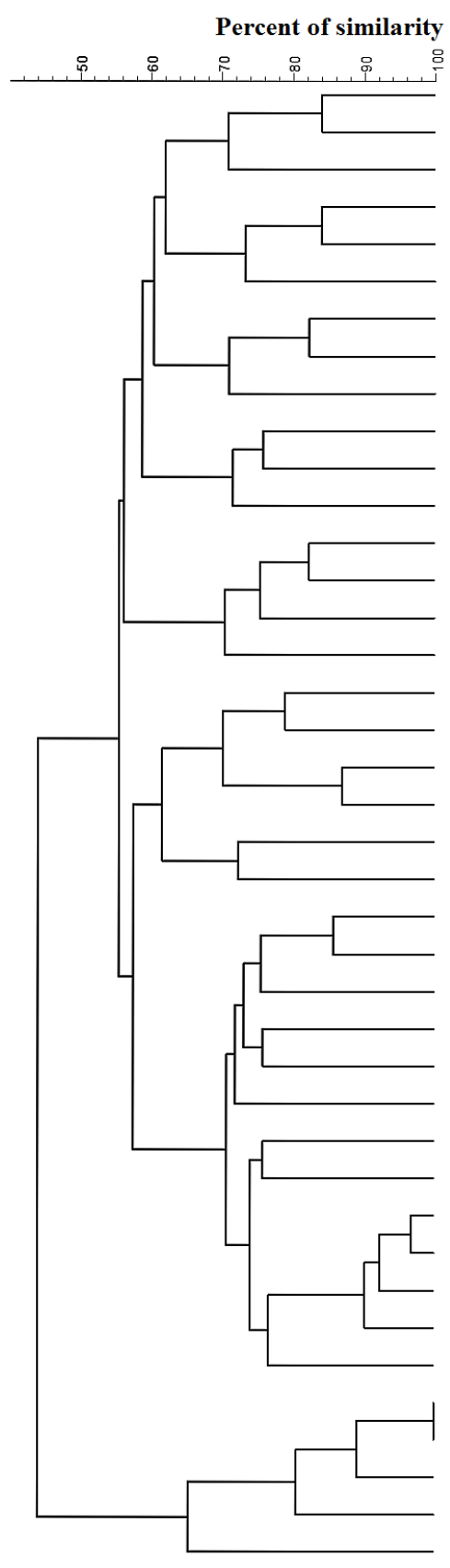

Isolates / closest strain (identified by 16S rRNA)

Clusters
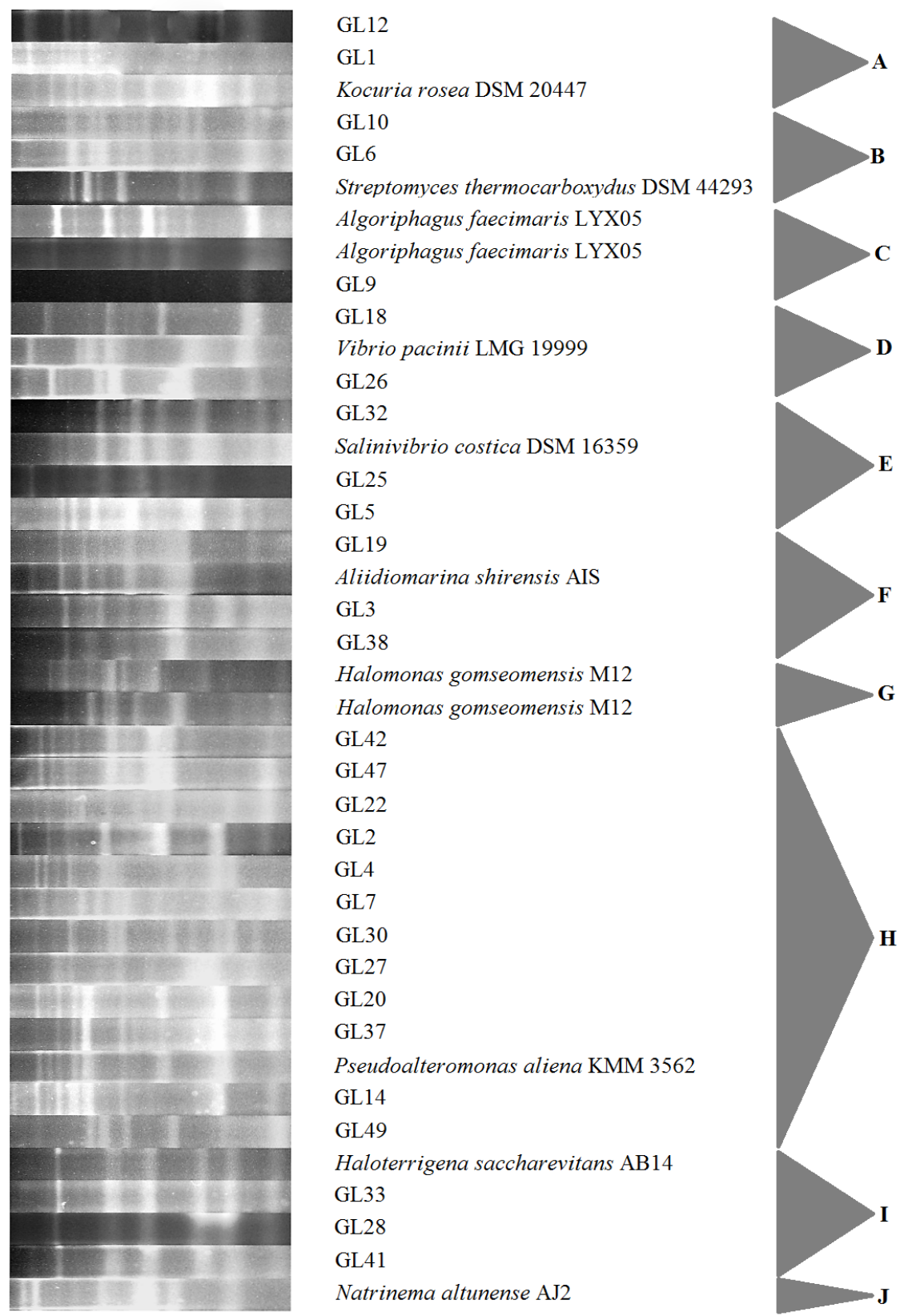

Figure 2. UPGMA dendrogram for the rep-PCR data calculated using the Jaccard coefficient from green region. The top bar indicates the percent of similarity. The letters on the right indicate the clusters formed in a $70 \%$ cut-off. 


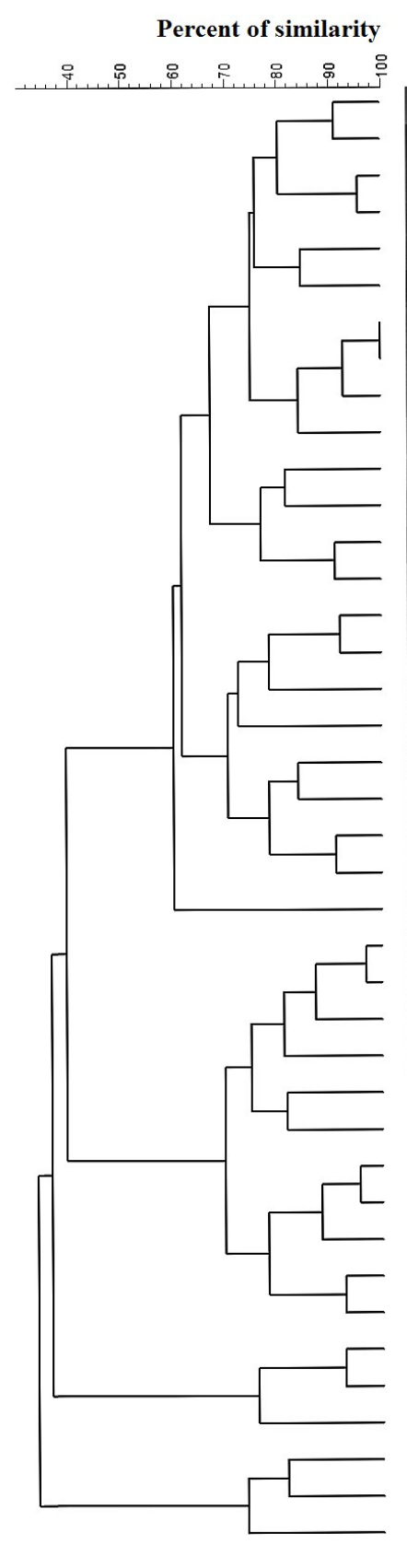

Isolates / closest strain (identified by $16 \mathrm{~S}$ rRNA) Clusters

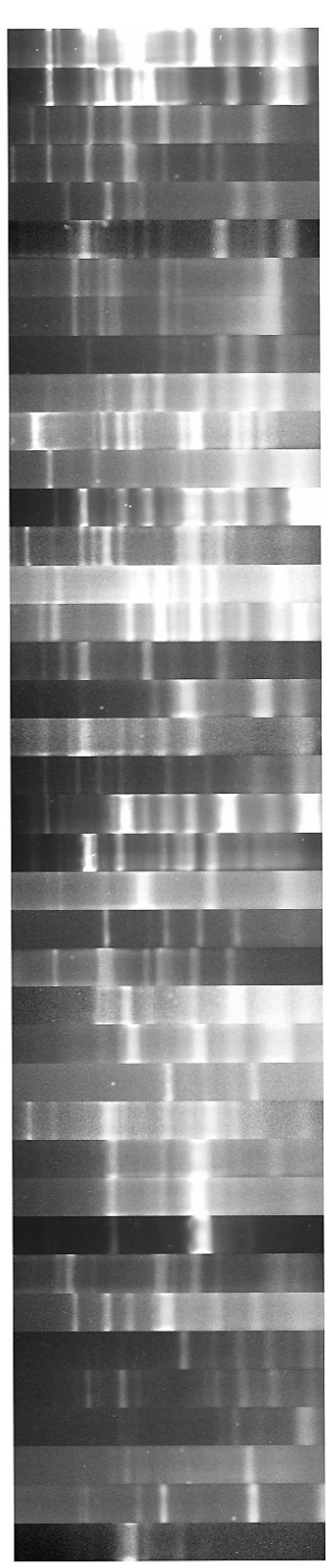

RL11
RL21
RL8
Bacillus licheniformis ATCC 14580
RL12
RL14
RL9
RL24
RL18
RL19
RL15
RL20
Gracilibacillus dipsosauri DD1
RL16
RL25
Thalassobacillus devorans G-19.1
RL26
RL32
RL39
Thalassobacillus devorans G-19.1
RL7
RL31
Piscibacillus halophilus CL-MP28
RL27
RL34
RL23
RL29
RL33
Halorubrum xinjiangense BD-1
RL22
RL38
RL6
Halorubrum xinjiangense BD-1
RL49
RL47
Haloarcula marismortui ATCC 43049
RL1
RL4
Natrinema altunense AJ2
RL2

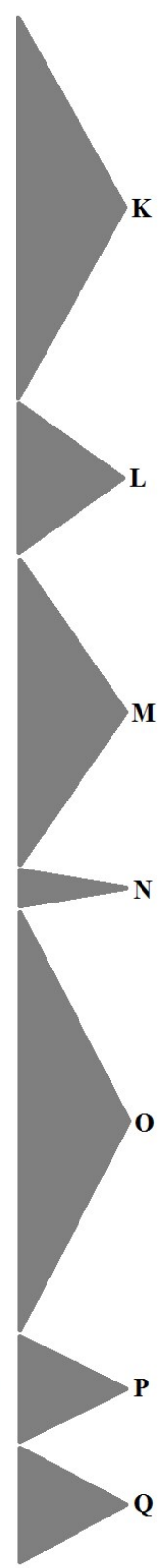

Figure 3. UPGMA dendrogram for the rep-PCR data calculated using the Jaccard coefficient from red region. The top bar indicates the percent of similarity. The letters on the right indicate the clusters formed in a $70 \%$ cut-off. 

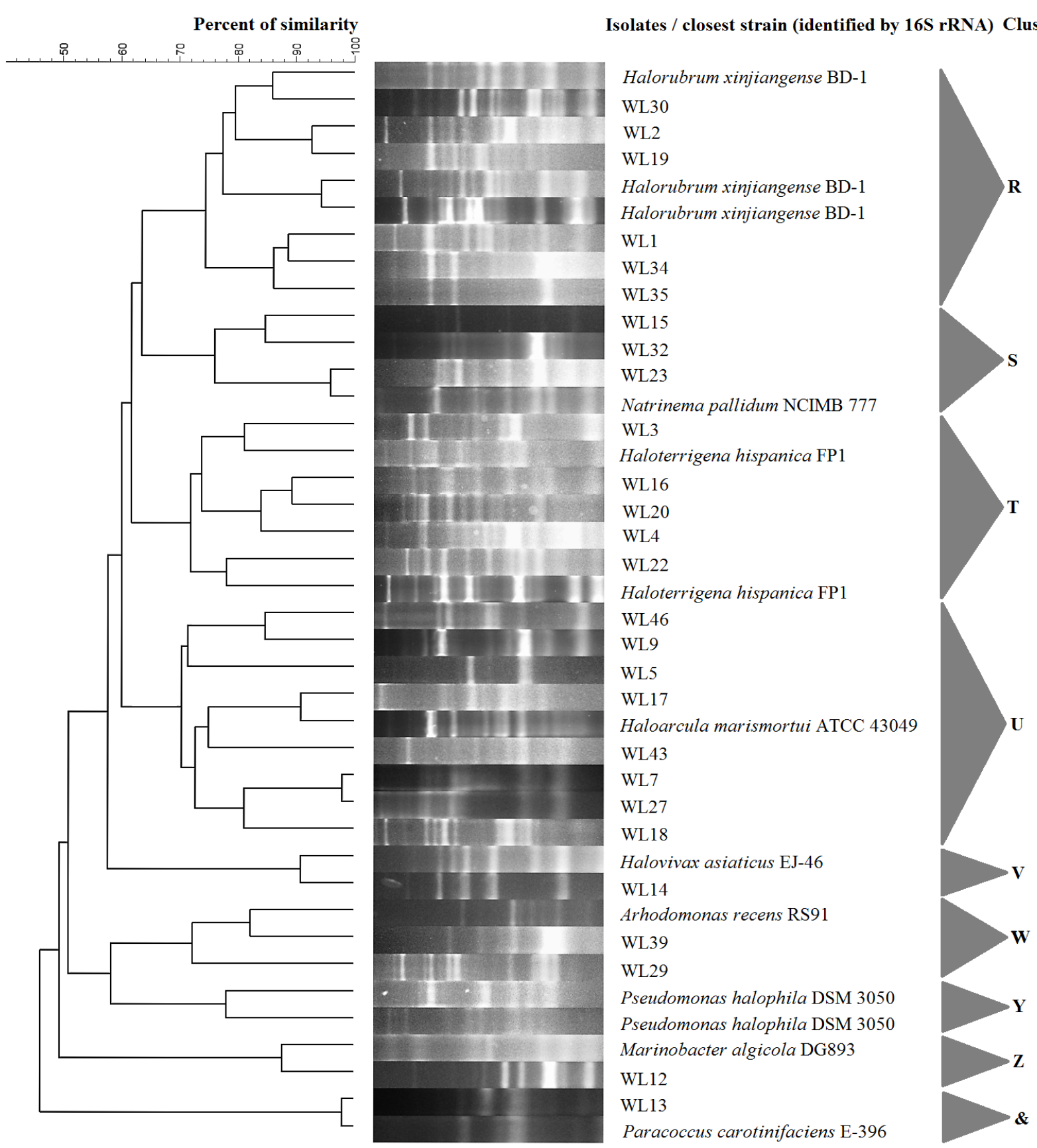

Figure 4. UPGMA dendrogram for the rep-PCR data calculated using the Jaccard coefficient from white region. The top bar indicates the percent of similarity. The letters on the right indicate the clusters formed in a 70\% cut-off.

The combination of the rep-PCR along with 16S rRNA gene sequencing allowed identifying 120 strains. In the white region more isolated strains $(77.5 \%)$ belonged to the family Halobacteriacae (Halorubrum $22.5 \%$, Halorcula $22.5 \%$, Haloterrigena $17.5 \%$, Natrinema $10 \%$ and Halovivax $5 \%$ of isolates obtained) and the remaining $22.5 \%$ of isolates belonged to bacteria, Arhodomonas, Pseudomonas, Marinobacter and Paracoccus. In red region isolated strains (57.5\%) belonged to Bacillaceae (Bacillus $25 \%$ of isolates obtained, Thalassobacillus $20 \%$ of isolates obtained, Gracilibacillus $10 \%$ of isolates obtained, and Piscibacillus $2.5 \%$ of isolates obtained) and the remaining $42.5 \%$ of isolated strains belonged to archaea, Halorubrum $27.5 \%$, and Haloarcula $15 \%$. In green region isolated strains belonged to the following genera: Pseudoalteromonas (32.5\%), Salinivibrio (10\%), Aliidiomarina (10\%), Haloterigena (10\%), Kocuria (7.5\%), Streptomyces (7.5\%), Algoriphagus (7.5\%), Vibrio (7.5\%), Halomonas (5\%) in domain of bacteria, and Natrinema $(2.5 \%)$ in archaea. 
Overall, 34 representative isolated strains for all regions and each clusters were subjected to $16 \mathrm{~S}$ rRNA genes sequencing analysis. These data revealed the presence of Gammaproteobacteria, Alphaproteobacteria, Actinobacteria, Bacilli, Bacteroidetes and Halobacteria in Lake Meyghan (Fig. 5 and 6). Sequences belonging to archaea especially Halobacteria were found in white region more than red and green regions with 8,4 , and 2 strains, respectively. The Halobacteria was most diverse with ten OTUs, followed by the Gammaproteobacteria with ten OTUs and the Bacilli with five OTUs (Fig. 5 and 6).

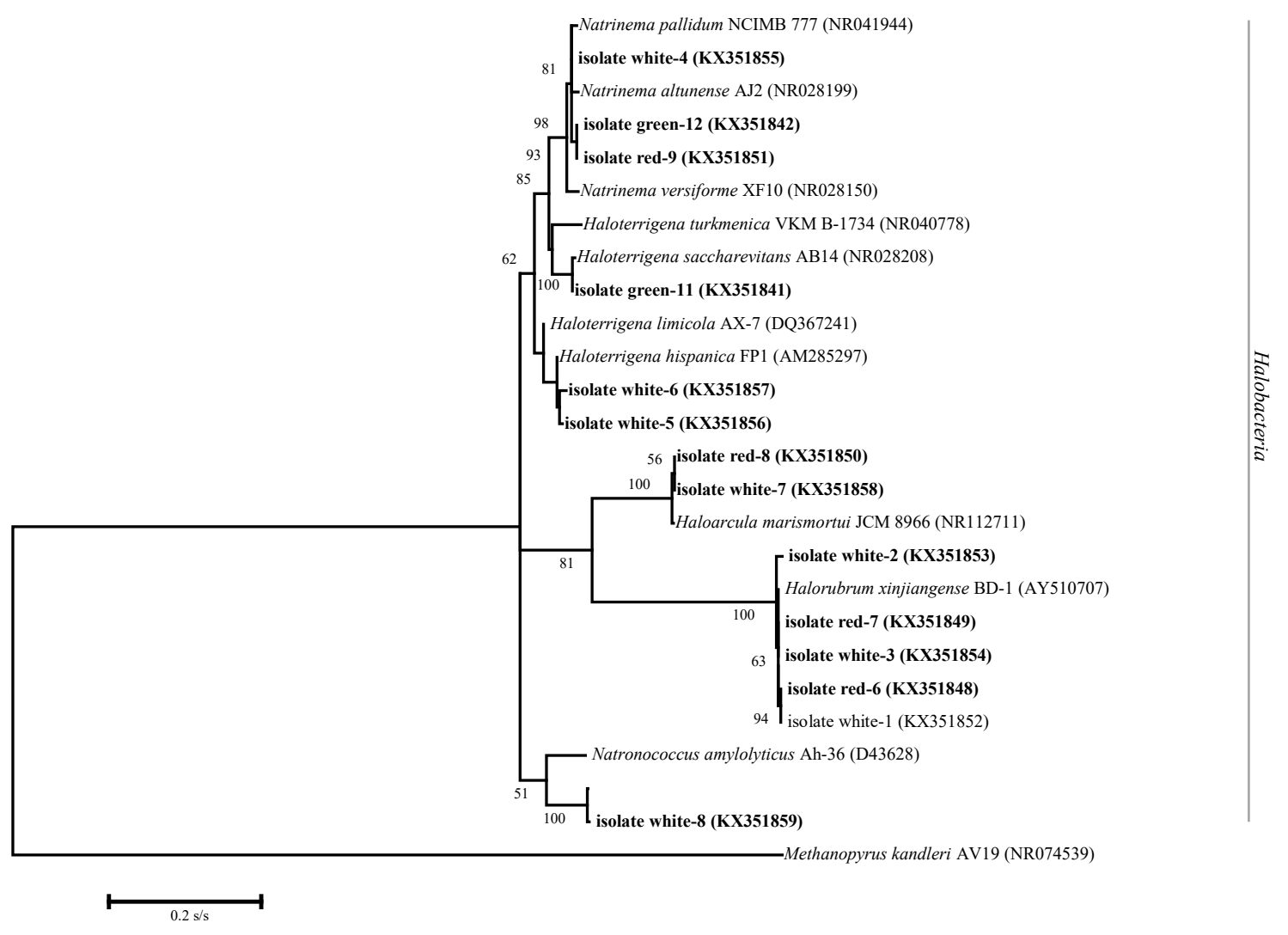

Figure 5. Phylogenetic reconstruction of 16S rRNA of archaeal sequences recovered from Lake Meyghan. The most likely topology shown here was obtained under the General-Time-Reversible substitution model with gamma distributed rate heterogeneity and a proportion of invariable sites $(\mathrm{GTR}+\Gamma+\mathrm{I})$. Bootstrap analysis was performed with 100 replicates and values greater than 50\% are shown. Scale represents the expected number of substitutions per site. 


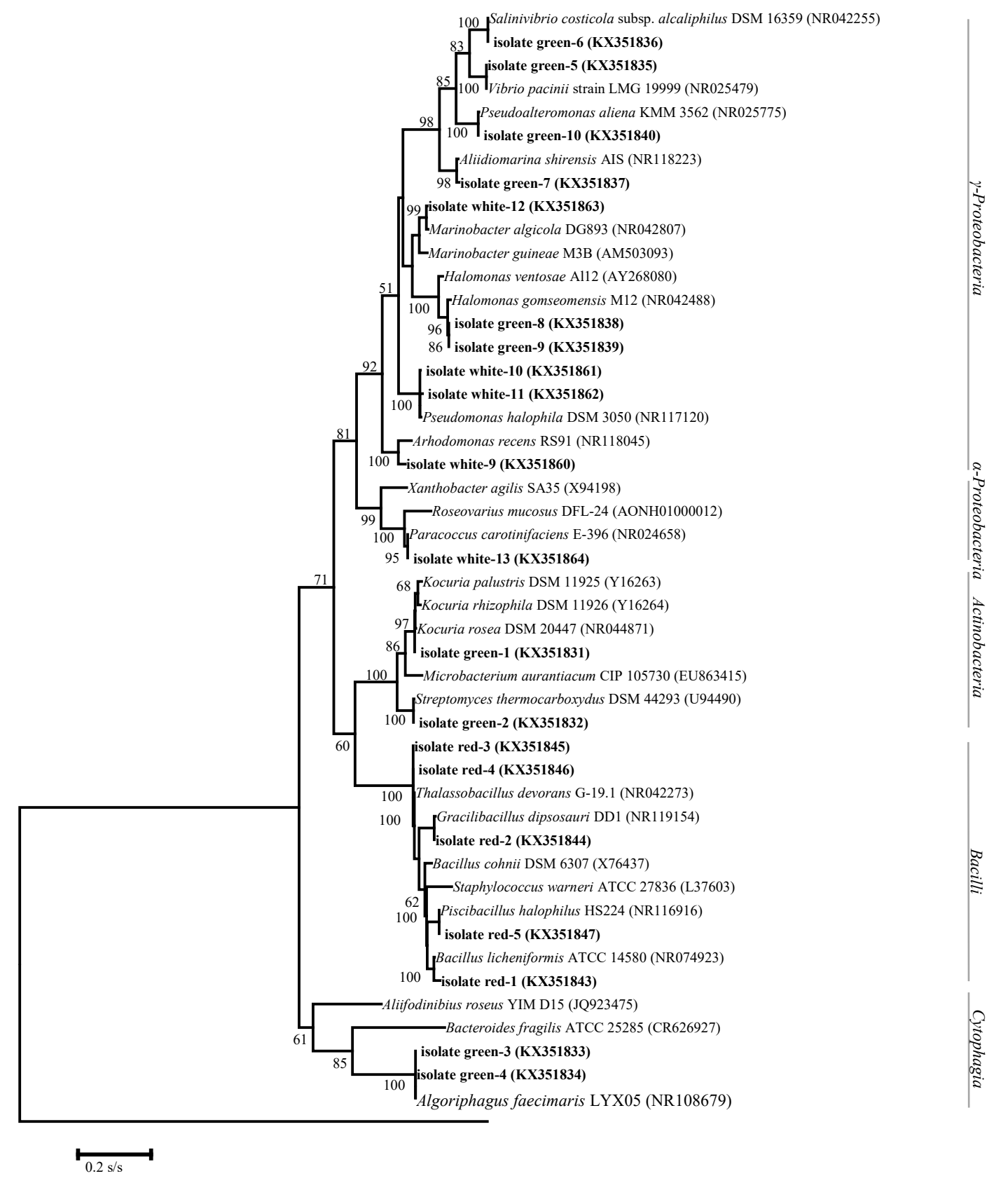

Figure 6. Phylogenetic reconstruction of $16 \mathrm{~S}$ rRNA of bacterial sequences recovered from Lake Meyghan. The most likely topology shown here was obtained under the General-Time-Reversible substitution model with gamma distributed rate heterogeneity and a proportion of invariable sites $(\mathrm{GTR}+\Gamma+\mathrm{I})$. Bootstrap analysis was performed with 100 replicates and values greater than $50 \%$ are shown. Scale represents the expected number of substitutions per site.

\section{Discussion}

Iran has a great diversity of saline and hypersaline environments that prokaryotes population needs to be elucidated. These include permanent hypersaline lakes such as Lake Urmia in the North West and seasonal hypersaline lakes such as Aran-Bidgol and Howz-e Soltan in the center of Iran. Jookar Kashi et al. [47] studied cultivable microorganisms in Urmia Lake and found that their isolates belonged to Proteobacteria (21.4\%), Firmicutes (78.6\%), and Actinobacteria (1.8\%). Lake Meyghan is one of the most important hypersaline playa in Iran, because of its mineable sodium sulfate deposit that is the largest in the Middle East. According to its physicochemical properties, this lake was classified as thalassohaline [46]. The ion composition of Lake Meyghan reflected that 
of seawater: $\mathrm{Na}^{+}$was the dominant cation, $\mathrm{Cl}^{-}$was the dominant anion. The $\mathrm{pH}$ was about between 7.7 to 8.8. We used qPCR to calculate microbial total cells and number of bacteria and archaea in different regions of the lake. This technique is one of the best methods, used by researchers to estimate the number of cells in the environment because with this technique number of culturable and non-culturable bacteria and archaea cells determined. Total prokaryote cell counts in the lake in green, red, and white regions were $8.1 \times 10^{6}\left(\right.$ cells mL $\left.\mathrm{mL}^{-1}\right), 5.5 \times 10^{6}\left(\right.$ cells mL$\left.{ }^{-1}\right)$, and $3.6 \times 10^{6}$ (cells $\mathrm{mL}^{-1}$ ), respectively, and in the range of the microbial populations found in other similar environments studied $\left(10^{6}-10^{7}\right.$ cells $\left.\mathrm{mL}^{-1}\right)$, but lower than some other environmental investigations, perhaps the reason for this due to the fact that toxic sulfur compounds exist in this environment [46, 48]. Salterns in Santa Pola (Spain) contained $1 \times 10^{7}$ to $5 \times 10^{7}$ cells $\mathrm{mL}^{-1}(49,50)$. Mutlu et al. (2008) found that the total cell counts per milliliter were $1.38 \times 10^{7}$ in the Tuz Lake, a hypersaline environment in Inland Turkey [48]. And also, Makhdoumi-Kakhki et al. [46] calculated that the total cells in the Aran-Bidgol Salt Lake in Iran around $3-4 \times 10^{7}$ cells $\mathrm{mL}^{-1}$ and $50-75 \%$ and $18-$ $37 \%$ of detected cells related to archaea and bacteria, respectively.

The objective of performing rep-PCR in this study was to estimate genetic similarity among the bacterial and archaeal isolates. Screening of isolates using rep-PCR technique is inexpensive, easy, and rapid. Despite the fact that the majority of the rep-PCR DNA studies have been carried out for epidemiological and strain tracking purposes, this technique also enjoys great versatility and can be adopted to study microbial community, ecology, and evolution. Comparative studies conducted suggest that rep-PCR is a rapid method for characterising taxonomic diversity and phylogenetic structure [33]. Aanniz et al. (2015) investigated the diversity of thermophilic bacteria in hot springs, salt marshes, and desert soils in Moroccan by using rep-PCR along with 16S rRNA gene sequencing techniques [25]. The combination of these two methods allowed the researchers to identified 219 isolates $(91.25 \%)$ to the species level. The researchers indicate that these techniques were a powerful tool for identification of bacteria to the species level [25]. Kathleen et al. (2014) used rep-PCR analysis and 16S rRNA sequencing to investigate the diversity of bacteria in Sarawak. Researchers stated that rep-PCR method had a high discrimination power when compared to other DNA fingerprinting techniques and can be reduce the cost for DNA sequencing [26]. Also, De Bellis et al. (2015) used rep-PCR along with 16S rRNA gene sequencing techniques to survey the biodiversity of bacterial strains isolated from vineyard soils [27].

After the dendrograms were generated based on the rep-PCR analysis, the representative isolates for each region and each cluster were subjected to $16 \mathrm{~S}$ rRNA genes sequencing analysis. Among the 120 screened bacteria and archaea isolated strains from these three regions, 34 representative strains were selected for identification using 16S rRNA PCR analysis and DNA sequencing. The combination of the rep-PCR along with 16S rRNA gene sequencing allowed identifying 120 isolates, the cost of which was equal to the amount needed for just sequencing of 34 isolates and this method can be useful when we want excellent information about the diversity of a region in a very rapid and inexpensive way.

In the present study, the rep-PCR technique similarly revealed considerable diversity between isolates, generating a dendrogram with 10,7 , and 9 clusters for a $70 \%$ similarity cut-off for the green, red, and white regions, respectively. The bacteria distribution in green region is more diverse than red and white regions, while the white region is the least diverse region due to high concentration of saline in these regions. In the white region more isolated strains $(77.5 \%)$ belonged to Halobacteriacae and many isolates were related to the genera Halorubrum and Haloarcula as could be expected because of the high salt concentration existed in this region and our qPCR result showed that archaea were the dominant microbes in this region. This is consistent with previous reports, Makhdoumi-Kakhki et al. (2012), who studied 101 archaeal isolates from Aran-Bidgol Salt Lake in Iran and found that their isolates belonged to Halobacteriacae family, with Halorubrum and Haloarcula being the most abundant [46]. In surveys performed in IncheBoroun wetland in Iran the archaeal isolates were belonged to Haloarcula (30\%) and Halorubrum (27.5\%) [51]. Results of other studies conducted in other hypersaline habitats of the world shows that members of Halorubrum constitute $70 \%$ of the isolates of solar slatterns in Australia and in Ayakekumu salt 
lake in China 47\% of isolates belonged to genus Halorubrum [52], also in Maras lake in Peru 50\% of the isolates belonged to genus Haloarcula [53]. In the red region of Lake Meyghan more isolates (57.5\%) belonged to Bacillaceae and the remaining $42.5 \%$ isolates belonged to archaea; Halorubrum, and Haloarcula but the result of qPCR showed that this region had more archaea cells than bacteria. Perhaps the reason for this is the different approaches with these two techniques. We found that Bacillaceae was the most cultarable prokaryotes in this region but in qPCR because of counting cultarable and non-cultarable prokaryotes we saw that archaea were the dominant prokaryotes in this region. So this is the reason for unsuccessful isolation Haloquadratum walsbyi in red and white regions that was dominated in other similar hypersaline environments. Of course, usually the cultivation of these microorganisms is difficult but, we can show it by culture independent techniques. Makhdoumi-Kakhki et al. (2012), stated that $40 \%$ of the archaeal sequences from Aran-Bidgol Salt Lake were related to Haloquadratum walsbyi by using denaturing gradient gel electrophoresis (DGGE) analysis [46]. Mutlu et al. (2008) found that Haloquadratum spp. were the main components of the microbiota in Tuz Lake in Turkey [48]. So we can conclude that the dominant prokaryotes in this region were archaea but the most culturable prokaryotes were bacteria belonging to Bacillaceae. Also, isolation of members of the Bacillaceae, were previously reported by Dhiraj Paul et al. from Lonar Lake [54]. Our data demonstrated that the contributions of bacteria versus archaea also changed with increasing salinity with bacteria being the dominant group at low salinity (green region with 5\% salinity) and archaea becoming more dominant at the highest salinity (white region with 30\% salinity), we expected to find more diversity in green region than two other regions, and the result is a testimony to this claim. We recovered members of Gammaproteobacteria, found to constitute an important component in both saline and alkaline lakes [18, 19, 46]. Green region of Lake Meyghan is dominant with Pseudoalteromonas, Salinivibrio, and Aliidiomarina. Benlloch et al. (2002) investigated prokaryotic diversity of three salt ponds $(8,22$, and $32 \%$ total salts, respectively) by using DGGE analysis and 16S rRNA gene sequencing from Santa Pola saltern in Spain. Most bacterial sequences in the $8 \%$ salt pond were belonged to Proteobacteria [55]. And also, Dhiraj Paul et al. (2016) found that Proteobacteria were the most predominant phyla, and Within the Proteobacteria members of Gammaproteobacteria were the most abundant [54].

\section{Conclusion}

In this study prokaryotic biodiversity from three sites of Lake Meyghan was investigated by using rep-PCR along with 16S rRNA gene sequencing. Based on rep-PCR and 16S rRNA gene sequencing, the recovered isolates were dominated by $(77.5 \%)$ Halobacteriacae and many isolates were related to the genera Halorubrum, Haloarcula, Haloterrigena, Natrinema, and Halovivax in the white region with $30 \%$ salinity. In the red region with $20 \%$ salinity more isolated strains (57.5\%) belonged to Bacillaceae and the remaining $42.5 \%$ of isolates belonged to archaea domain, Halorubrum, and Haloarcula. In the green region with 5\% salinity we found most isolates belonged to Gammaproteobacteria. Our data demonstrated that the contributions of bacteria versus archaea also changed with increasing salinity with bacteria being the dominant group at low salinity (green region with 5\% salinity) and archaea becoming more dominant at the highest salinity (white region with $30 \%$ salinity). The rep-PCR technique along with $16 \mathrm{~S}$ rRNA gene sequencing technique can be a good choice when we want to obtain quick and basic information about biodiversity from environmental samples in very cost effective, simple, and rapid way. In this study we found these two techniques useful to investigate biodiversity in Lake Meyghan. Of course, for more information about this lake we need further study using other techniques and approaches like using metagenomic to obtain more completely information about this unique environment, but these two techniques show us basic information about this unique environment and its prokaryotes diversity. 


\section{References}

[1] N.G. Hariston et al., The relationship between species diversity and stability: an experimental approach with protozoa and bacteria, Ecology. 49(6) (1968) 1091-1101.

[2] M.J. Swift, Species diversity and the structure of microbial communities in terrestrial habitats, in: J.M. Anderson, A. McFadyen (Eds.), The role of terrestrial and aquatic organisms in decomposition processes, Blackwell Scientific Publication, United Kingdom, 1974, pp. 185221.

[3] B.K. Singh et al., Soil genomics, Nature Rev. Microbiol. 7(10) (2009) 756-757.

[4] M.C. Horner-Devine, M.K. Carney, B.J.M. Bohannan, An ecological perspective on bacterial biodiversity, Proc. Biol. Sci. 271(1535) (2003) 113-122.

[5] F. Rodríguez-Valera et al., Variation of environmental features and microbial populations with salt concentrations in a multi-pond saltern, Microb. Ecol. 11(2) (1985) 107-115.

[6] A. Oren, Molecular ecology of extremely halophilic Archaea and Bacteria, FEMS Microbiol. Ecol. 39(1) (2002) 1-7.

[7] C. Pedrós-Alió et al., The microbial food web along salinity gradients, FEMS Microbiol. Ecol. 32(2) (2000) 143-155.

[8] E.O. Casamayor, J.I. Calderón-Paz, C. Pedrós-Alió, 5S rRNA fingerprints of marine bacteria, halophilic archaea and natural prokaryotic assemblages along a salinity gradient, FEMS Microbiol. Ecol. 34(2) (2000) 113-119.

[9] F. Rodríguez-Valera, F. Ruiz-Berraquero, A. Ramos-Cormenzana, Characteristics of the heterotrophic bacterial populations in hypersaline environments of different salt concentrations, Microb. Ecol. 7(3) (1981) 235-243.

[10] C. Lizama et al., Taxonomic study of extreme halophilic archaea isolated from the "Salar de Atacama', Chile, Syst. Appl. Microbiol. 24(3) (2001) 464-474.

[11] C. Lizama et al., Halorubrum tebenquichense sp nov., a novel halohilic archaeon isolated from the Atacama Saltern, Chile, Int. J. Syst. Evol. Microbiol. 52 (2002) 149-155.

[12] J. Antón et al., Salinibacter ruber gen. nov., sp. nov., a new species of extremely halophilic Bacteria from saltern crystallizer ponds, Int. J. Syst. Evol. Microbiol. 52 (2002) 485-491.

[13] R.M. Bond, Investigations of some Hispaniolan lakes. II. Hydrology and Hydrography, Arch. Hydrobiol. 28 (1935) 144-161.

[14] A. Ventosa, Unusual micro-organisms from unusual habitats: hypersaline environments, in: N.A. Logan, H.M. Lappin-Scott, P.C.F. Oyston (Eds.), Prokaryotic Diversity: Mechanism and Significance, Cambridge University Press, United Kingdom, 2006, pp. 223-253

[15] A.B. Fernández et al., Comparison of prokaryotic community structure from Mediterranean and Atlantic saltern concentrator ponds by a metagenomic approach, Front. Microbiol. 5 (2014) 196.

[16] N.H. Youssef, K.N. Ashlock-Savage, M.S. Elshahed, Phylogenetic diversities and community structure of members of the extremely halophilic Archaea (Order Halobacteriales) in multiple saline sediment habitats, Appl. Environ. Microbiol. 78 (2012) 1332-1344

[17] M. Birbir et al., Extremely halophilic Archaea from Tuz Lake, Turkey, and the adjacent Kaldirim and Kayacik salterns, World J. Microbiol. Biotechnol. 23(3) (2007) 309-316. 
[18] H. Jiang et al., Microbial diversity in water and sediment of Lake Chaka, an athalassohaline lake in northwestern China, Appl. Environ. Microbiol. 72(6) (2006) 3832-3845.

[19] L. Maturrano et al., Microbial diversity in Maras salterns, a hypersaline environment in the Peruvian Andes, Appl. Environ. Microbiol. 72(6) (2006) 3887-3895.

[20] S. Benlloch et al., Archaeal biodiversity in crystallizer ponds from a solar saltern: culture versus PCR, Microb. Ecol. 41(1) (2001) 12-19.

[21] C.D. Litchfield, P.M. Gillevet, Microbial diversity and complexity in hypersaline environments: a preliminary assessment, J. Ind. Microbiol. Biotechnol. 28(1) (2002) 48-55.

[22] C.W. Lin et al., Comparison of pulsed-field gel electrophoresis and three rep-PCR methods for evaluating the genetic relatedness of Stenotrophomonas maltophilia isolates, Lett. Appl. Microbiol. 47(5) (2008) 393-398.

[23] L.G. Dos Anjos Borges, V. Dalla Vechia, G. Corção, Characterisation and genetic diversity via REP-PCR of Escherichia coli isolates from polluted waters in southern Brazil, FEMS Microbiol. Ecol. 45(2) (2003) 173-180.

[24] J.V. Versalovic, F.J. de Bruijn, J.R. Lupski, Repetitive sequence-based PCR (rep-PCR) DNA fingerprinting of bacterial genomes, in: F.J. de Bruijn, J.R. Lupski, G.M. Weinstock (Eds.), Bacterial Genomes: Physical Structure and Analysis, Chapman \& Hall, USA, 1998, pp. 437454.

[25] T. Aanniz et al., Thermophilic bacteria in Moroccan hot springs, salt marshes and desert soils, Braz. J. Microbiol. 46(2) (2015) 443-453.

[26] M.M. Kathleen et al., (GTG) $)_{5}$ PCR analysis and 16S rRNA sequencing of bacteria from Sarawak aquaculture environment, International Food Research Journal. 21(3) (2014) 915920.

[27] P. De Bellis et al., Biodegradation of Ochratoxin A by bacterial strains isolated from Vineyard soils, Toxins. 7(12) (2015) 5079-5093.

[28] D.W. Ussery et al., Genome update: DNA repeats in bacterial genomes, Microbiology. 150 (2004) 3519-3521.

[29] S. Ishii, M.J. Sadowsky, Applications of the rep-PCR DNA fingerprinting technique to study microbial diversity, ecology and evolution, Environ. Microbiol. 11(4) (2009) 733-740.

[30] R. Tobes, J.L. Ramos, REP code: defining bacterial identity in extragenic space, Environ. Microbiol. 7(2) (2005) 225-228.

[31] M.J. Sadowsky, H.G. Hur, Use of endogenous repeated sequences to fingerprint bacterial genomic DNA, in: F.J. de Bruijn, J.R. Lupski, G.M. Weinstock (Eds.), Bacterial Genomics: Physical Structure and Analysis editors, Chapman \& Hall, USA, 1998, pp. 399-413.

[32] J. Versalovic, J.R. Lupski, Interspersed repetitive sequences in bacterial genomes, in: F.J. de Bruijn, J.R. Lupski, G.M. Weinstock (Eds.), Bacterial Genomics: Physical Structure and Analysis editors, Chapman \& Hall, USA, 1998. pp. 38-48.

[33] J.L.W. Rademaker et al., Characterization of the diversity of ecologically important microbes by rep-PCR genomic fingerprinting, in: G.A. Kowalchuck et al. (Eds.), Molecular Microbial Ecology Manual, Springer, The Netherlands, 2008, pp. 611-644.

[34] H. Rahimpour-Bonab, L. Abdi, Sedimentology and origin of Meyghan lake/playa deposits in Sanandaj-Sirjan zone, Iran, Carbonates Evaporites. 27(3) (2012) 375-393. 
[35] D.G. Burns et al., Combined use of cultivation-dependent and cultivation-independent methods indicates that members of most haloarchaeal groups in an Australian crystallizer pond are cultivable, Appl. Environ. Microbiol. 70(9) (2004) 5258-5265.

[36] S. Benlloch et al., Description of prokaryotic biodiversity along the salinity gradient of a multipond solar saltern by direct PCR amplification of 16S Rdna, Hydrobiologia. 329(1) (1996) 19-31.

[37] N.M. Nathani et al., Comparative evaluation of rumen metagenome community using qPCR and MG-RAST, AMB Express. 3(1) (2013) 55.

[38] D.J. Lane, 16S/23S rRNA sequencing in: E. Stackebrandt, M. Goodfellow (Eds.), Nucleic acid techniques in bacterial systematics, John Wiley and Sons, United Kingdom, 1991, pp. $115-175$.

[39] S. Namwong et al., Isolation of Lentibacillus salicampi strains and Lentibacillus juripiscarius sp. nov. from fish sauce in Thailand, Int. J. Syst. Evol. Microbiol. 55 (2005) 315-320.

[40] K.M. Ritalahti et al., Quantitative PCR targeting 16S rRNA and reductive dehalogenase genes simultaneously monitors multiple Dehalococcoides strains, Appl. Environ. Microbiol. 72(4) (2006) 2765-2774.

[41] G. Muyzer, E.C. de Waal, A.G. Uitterlinden, Profiling of complex microbial populations by denaturing gradient gel electrophoresis analysis of polymerase chain reaction-amplified genes coding for 16S Rrna, Appl. Environ. Microbiol. 59(3) (1993) 695-700.

[42] L. Ovreås et al., Distribution of bacterioplankton in meromictic Lake Saelenvannet, as determined by denaturing gradient gel electrophoresis of PCR-amplified gene fragments coding for 16S Rrna, Appl. Environ. Microbiol. 63(9) (1997) 3367-3373.

[43] Y. Yu et al., Group-specific primer and probe sets to detect methanogenic communities using quantitative real-time polymerase chain reaction, Biotechnol. Bioeng. 89(6) (2005) 670-679.

[44] J. Versalovic, T. Koeuth, J.R. Lupski, Distribution of repetitive DNA sequences in eubacteria and application to fingerprinting of bacterial genomes. Nucleic Acids Res. 19(24) (1991) 6823-6831.

[45] K. Tamura et al., MEGA5: molecular evolutionary genetics analysis using maximum likelihood, evolutionary distance, and maximum parsimony methods, Mol. Biol. Evol. 28(10) (2011) 2731-2739.

[46] A. Makhdoumi-Kakhki et al., Prokaryotic diversity in Aran-Bidgol Salt Lake, the largest hypersaline playa in Iran, Microbes Environ. 27(1) (2012) 87-93.

[47] F. Jookar Kashi et al., Diversity of cultivable microorganisms in the eastern part of Urmia Salt Lake, Iran, J. Microbiol. Biotech. Food Sci. 4(1) (2014) 36-43.

[48] M.B. Mutlu et al., Prokaryotic diversity in Tuz Lake, a hypersaline environment in Inland Turkey, FEMS Microbiol. Ecol. 65(3) (2008) 474-483.

[49] J. Antón et al., Fluorescence in situ hybridization analysis of the prokaryotic community inhabiting crystallizer ponds, Environ. Microbiol. 1 (1999) 517-523.

[50] J. Antón et al., Extremely halophilic Bacteria in crystallizer ponds from solar salterns, Appl. Environ. Microbiol. 66 (2000) 3052-3057.

[51] M. Rasooli et al., Isolation, Identification and extracellular enzymatic activity of culturable extremely halophilic archaea and bacteria of IncheBoroun wetland, International Letters of Natural Sciences. 56 (2016) 40-51. 
[52] X. Xu et al., Culturable halophilic archaeal diversity of Ayakekumu Salt Lake located in Xinjiang, China, Acta Ecologica Sinica. 27(8) (2007) 3119-3123.

[53] R. Elevi et al., Characterization of extremely halophilic Archaea isolated from the Ayvalik Saltern, Turkey, World Journal of Microbiology and Biotechnology. 20(7) (2004) 719-725.

[54] D. Paul et al., Exploration of microbial diversity and community structure of Lonar Lake: The only hypersaline meteorite crater lake within basalt rock, Front. Microbiol. 6 (2015) 1553.

[55] S. Benlloch et al., Prokaryotic genetic diversity throughout the salinity gradient of a coastal solar saltern, Environ. Microbiol. 4 (2002) 349-360. 